\title{
Images in paediatrics: subcutaneous fat necrosis causing radial nerve palsy
}

\author{
Shahzad Haider \\ Department of Paediatrics, Macclesfield District General Hospital, Cheadle, UK
}

Correspondence to Dr Shahzad Haider, drhaider786@hotmail.com

\section{DESCRIPTION}

A baby boy was born at term by forceps extraction following uneventful pregnancy. The baby did not require resuscitation at birth. On routine postnatal check, it was noticed that the baby had left-sided wrist drop (figure 1). An area of palpable subcutaneous nodules with some erythema was identified over the lower part of left arm (figure 2). It was thought to be subcutaneous fat necrosis which had most likely caused radial nerve palsy. There were no associated signs suggested for brachial plexus injury. There was good flexion at the elbow and normal movements at shoulder. There was no evidence of fracture in the upper limb on x-ray. He received physiotherapy in the form of splinting and passive movements to prevent secondary contractures. After 4 weeks, he started showing some minimal extension of the fingers. The skin over the area of fat necrosis was desquamated. At his 10 week follow-up, his left arm seemed completely recovered. He had full range of movements. There is limited literature available relating radial nerve palsy secondary to subcutaneous fat necrosis. It is thought to be due to intrauterine pressure effect and almost universally there is a good recovery. ${ }^{1}$ The actual incidence of radial nerve injury may be greater as a few cases are misinterpreted as mild Klumpke's palsies. ${ }^{2}$ Postnatal subcutaneous fat necrosis is found to be possible side effect of whole body cooling in cases of birth asphyxia. ${ }^{3}$

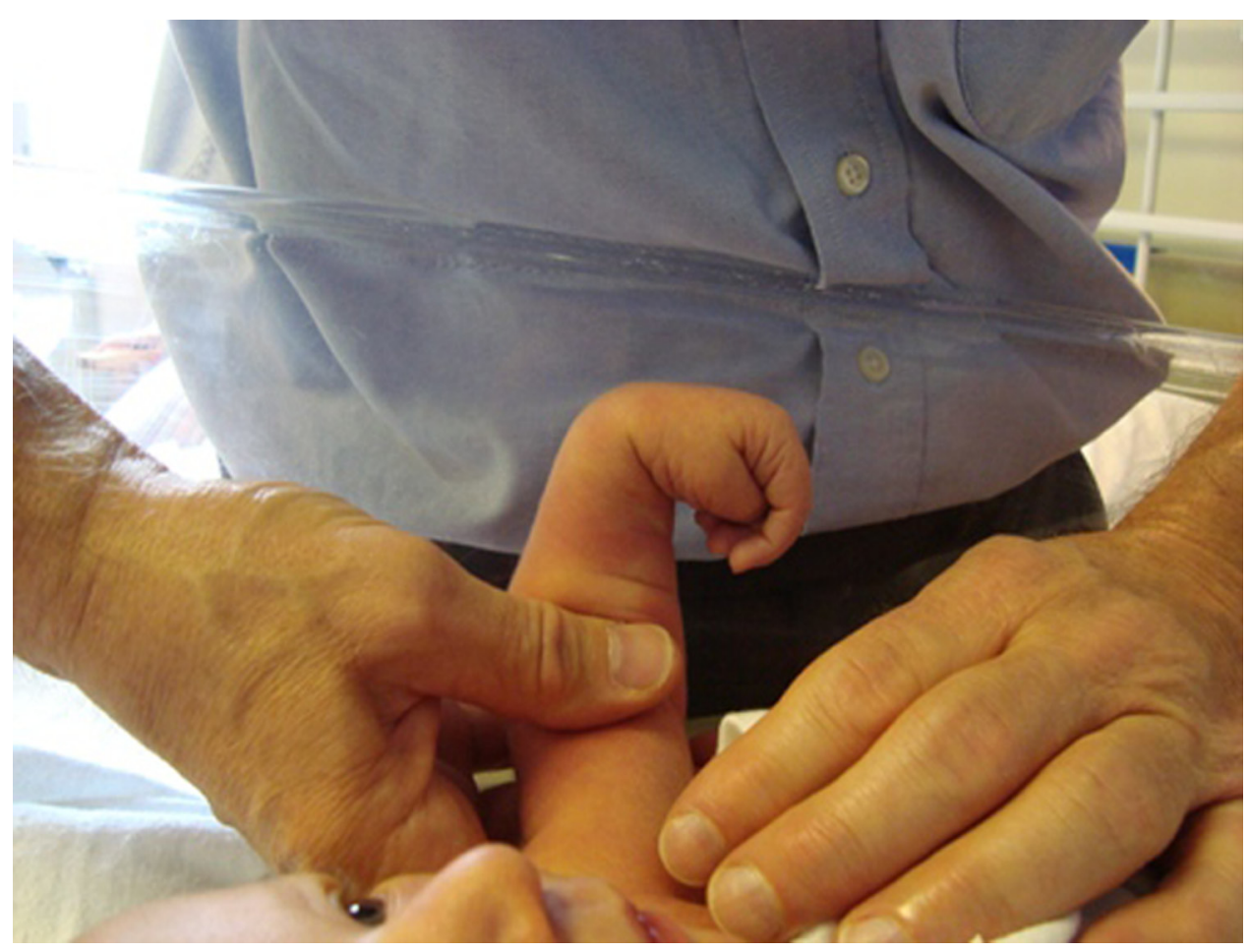

Figure 1 Left sided wrist drop due to radial nerve palsy. 


\section{BMJ Case Reports}

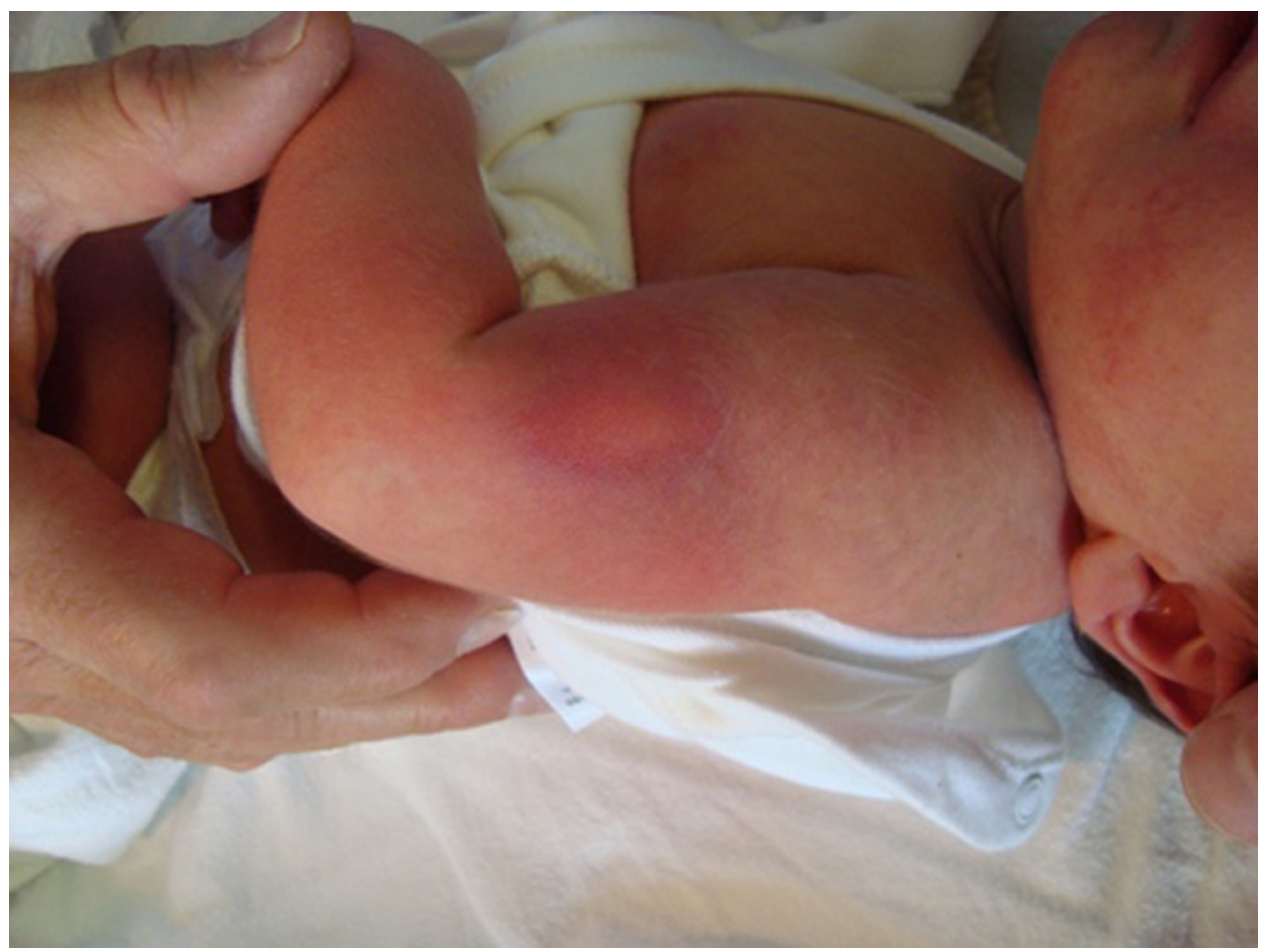

Figure 2 Subcutaneous fat necrosis on left arm soon after birth.

\section{Competing interests None.}

Patient consent Obtained.

\section{REFERENCES}

1. Monica JT, Waters PM, Bae DS. Radial nerve palsy in the newborn: a report of four cases and literature review. J Pediatr Orthop 2008;28:460-2.
2. Lenn NJ, Hamill JS. Congenital radial nerve pressure palsy. Clin Pediatr (Phila) 1983;22:388-9.

3. Oza V, Treat J, Cook N, et al. Subcutaneous fat necrosis as a complication of whole-body cooling for birth asphyxia. Arch Dermatol 2010;146:882-5.

This pdf has been created automatically from the final edited text and images.

Copyright 2012 BMJ Publishing Group. All rights reserved. For permission to reuse any of this content visit http://group.bmj.com/group/rights-licensing/permissions.

BMJ Case Report Fellows may re-use this article for personal use and teaching without any further permission.

Please cite this article as follows (you will need to access the article online to obtain the date of publication).

Haider S. Images in paediatrics: subcutaneous fat necrosis causing radial nerve palsy. BMJ Case Reports 2012;10.1136/bcr.10.2011.4904, Published XXX

Become a Fellow of BMJ Case Reports today and you can:

- Submit as many cases as you like

- Enjoy fast sympathetic peer review and rapid publication of accepted articles

- Access all the published articles

- Re-use any of the published material for personal use and teaching without further permission

For information on Institutional Fellowships contact consortiasales@bmjgroup.com

Visit casereports.bmj.com for more articles like this and to become a Fellow 